\title{
Morphogenetic and structural traits of Ipyporã grass subjected to nitrogen fertilization rates under intermittent grazing
}

\author{
Francisco Carlos Camargo ${ }^{1}$ (i) Gelson dos Santos Difante ${ }^{1}$ Denise Baptaglin Montagner $^{2}($ ) \\ Valéria Pacheco Batista Euclides ${ }^{2}\left(\mathbb{D}\right.$ Carolina de Arruda Queiroz Taira ${ }^{1}$ (D) \\ Antonio Leandro Chaves Gurgel ${ }^{*}$ (i) Daniele Lopes de Souza $^{3}(\mathbb{C}$
}

${ }^{1}$ Programa de Pós-graduação em Ciência Animal, Universidade Federal de Mato Grosso do Sul (UFMS), 79074-460, Campo Grande, MS, Brasil. E-mail: antonioleandro09@gmail.com. "Corresponding author.

${ }^{2}$ Embrapa Gado de Corte, Campo Grande, MS, Brasil.

${ }^{3}$ Universidade Católica Dom Bosco (UCDB), Campo Grande, MS, Brasil.

\begin{abstract}
This study examined the effects of annual nitrogen $(N)$ rates of 100 and $200 \mathrm{~kg} \mathrm{ha}^{-1}$ on the morphogenetic and structural traits of Ipyporã grass (Brachiaria brizantha $\times$ Brachiaria ruziziensis) under intermittent grazing during the seasons of the year. The experiment was laid out in a randomized-block design with two treatments and three area replicates. Ipyporã grass pastures were grazed by beef cattle. Morphogenetic and structural traits of the forage canopy were evaluated using the marked-tiller technique. Forage accumulation and tiller density (TD) were also evaluated. Significant interaction effects $(P<0.05)$ between $N$ rates and seasons were observed for the rest period, leaf lifespan (LLS), phyllochron, stem elongation rate (SER) and final leaf length (FLL). During winter, the rest period was shorter (40 vs. 50 days) in the pastures fertilized with $200 \mathrm{~kg} \mathrm{ha}^{-1} \mathrm{~N}$. Conversely, in winter, the pastures fertilized with $100 \mathrm{~kg} \mathrm{ha}{ }^{-1} \mathrm{~N} \mathrm{showed} \mathrm{higher} \mathrm{LLS,} \mathrm{SER} \mathrm{and}$ phyllochron values, but lower FLL values. There was no isolated effect of $N$ rates $(P>0.05)$ on forage accumulation rate; leaf appearance, elongation or senescence rates; leaf:stem ratio; or TD. However, the effect of seasons was significant for these variables, with the highest values occurring during spring and summer. The use of $200 \mathrm{~kg} \mathrm{ha}^{-1} \mathrm{~N}$ in Ipyporã grass pastures reduces the seasonality of forage production. Key words: Brachiaria, nitrogen fertilization, tissue flow, tropical pastures.
\end{abstract}

Características morfogênicas e estruturais do capim-ipyporã submetido a doses de adubação nitrogenada sob pastejo intermitente

RESUMO: O objetivo foi avaliar os efeitos das doses anuais de 100 e $200 \mathrm{~kg} \mathrm{ha} \mathrm{H}^{-1}$ de nitrogênio (N) sobre as características morfogênicas e estruturais do capim-ipyporã em lotação intermitente durante as estações do ano. O delineamento experimental foi em blocos ao acaso, com dois tratamentos e três repetições de área. Os pastos de capim-ipyporã foram submetidos ao pastejo por bovinos de corte. Foram avaliadas as características morfogênicas e estruturais do dossel forrageiro por meio da técnica de perfilhos marcados. Também foi avaliado o acúmulo de forragem e a densidade populacional de perfilhos $(D P P)$. Foi observada interação significativa $(P<0,05)$ das doses de $N$ e estações do ano para o periodo de descanso (PD), duração de vida das folhas (DVF), filocrono, taxa de alongamento de colmos (TAlC) e comprimento final das folhas (CFF). Durante o inverno, o PD foi menor (40 vs 50 dias) nos pastos adubados com $200 \mathrm{~kg} \mathrm{ha} \mathrm{l}^{-1} \mathrm{de} \mathrm{N}$. Em contra partida, no inverno, os pastos adubados com $100 \mathrm{~kg} \mathrm{ha}{ }^{-1}$ de $N$ apresentaram maiores valores para DVF, filocrono e TAlC, e menores para o CFF. Não foi observado efeito isolado de doses de $N(P>0,05)$ para as taxas de acúmulo de forragem; de aparecimento, alongamento e de senescência de folhas, relação folha:colmo e para a DPP. No entanto, o efeito das estações foi significativo para estas variáveis, com os maiores valores observados durante a primavera e verão. O uso de $200 \mathrm{~kg} \mathrm{ha}^{-1}$ de $\mathrm{N}$ para pastos de capim-ipyporã promove redução da estacionalidade de produção da forrageira.

Palavras-chave: Brachiaria, fertilização nitrogenada, fluxo de tecido, pastos tropicais.

\section{INTRODUCTION}

Ipyporã grass is an interspecific Brachiaria hybrid (B. brizantha $\times$ B. ruziziensis) with antibiosis resistance to the froghopper (Notozulia entreriana, Deois flavopicta, Mahanarva fimbriolata and Mahanarva sp.) (VALLE et al., 2017). Under grazing incidence, this cultivar showed better leaf:stehgm ratios and nutritional value when compared with Marandu grass (Brachiaria brizantha cv. Marandu), and these traits provided better individual animal gains (EUCLIDES et al., 2018).

ECHEVERRIA et al. (2016) evaluated this forage plant under grazing activity, based on the concept of light interception (LI) by the canopy, to determine the appropriate time for animals to enter 
the paddocks, in intermittent grazing. The authors concluded that the cultivar should be grazed when the canopy height reaches $30 \mathrm{~cm}(95 \% \mathrm{LI})$ and that the animals should be removed from the paddocks when stubble height reaches $15 \mathrm{~cm}$. Deemed responsive to soil fertility, Ipyporã grass is recommended for medium-fertility soils along with the use of maintenance fertilization (VALLE et al., 2017).

The productive potential of a forage cultivar is expressed genetically, but environmental factors (temperature, precipitation, nutrients) and management may affect this response differently, as they influence the canopy leaf area index and forage accumulation potential (MONTAGNER et al., 2012; ALVARENGA et al., 2020). Nitrogen (N) fertilization is used in pastures as a management tool to increase pasture production capacity, reduce rest periods and increase carrying capacity (GURGEL et al., 2021). Considered fuel for plant cells, $\mathrm{N}$ provides an increase in tissue flow (appearance and death) and can modify the structural traits of the canopy (FARIAS et al., 2019 ) if there is no control over grazing.

In tropical forages, responses to $\mathrm{N}$ application are evidenced as improved forage accumulation (YASUOKA et al., 2018), nutritional value (CASTAGNARA et al., 2011), morphogenetic traits (VASCONCELOS et al., 2020) and animal production (GIMENES et al., 2011). Compared with marandu grass, Ipyporã grass pastures had a lower carrying capacity due to its lower forage production potential (EUCLIDES et al., 2018). In this respect, $\mathrm{N}$ fertilization can be adopted as an alternative for the cultivar to express its maximum genetic potential for forage production. This strategy may lessen the impact of production seasonality, which, despite being a process inherent to tropical forage grasses, can be minimized through pasture and grazing management practices (MARTINS et al., 2021).

Therefore, considering that $100 \mathrm{~kg} \mathrm{ha}^{-1}$ is the minimum recommended $\mathrm{N}$ rate for Brachiaria cultivars under grazing incidence (MARTHA JÚNIOR et al., 2007) and that higher Nlevels can increase tissue turnover (FARIAS et al.., 2019), we conducted an experiment to test the hypothesis that fertilization with higher $\mathrm{N}$ rates can reduce the seasonality of forage production. The present study examined the effects of annual $\mathrm{N}$ rates of 100 and $200 \mathrm{~kg} \mathrm{ha}^{-1}$ on the morphogenetic and structural traits of Ipyporã grass under intermittent grazing during the seasons of the year.

\section{MATERIALS AND METHODS}

The experiment was developed in the experimental area of Embrapa Beef Cattle $\left(20^{\circ} 27^{\prime} \mathrm{S}\right.$ and $54^{\circ} 37^{\prime} \mathrm{W}, 530 \mathrm{~m}$ asl), from November 2015 to October 2016. The climate of the region is classified as tropical rainy savanna (Aw subtype), characterized by seasonal rainfall distribution (Köppen). Temperature and precipitation data during the experimental period were collected by the meteorological station at Embrapa Beef Cattle (Figure 1), located approximately $3.0 \mathrm{~km}$ from the experimental area.

The soil in the experimental area is classified as a clayey-textured Red Oxisol (EMBRAPA, 2013). Pastures of the Brachiaria ruziziensis $\times$ Brachiaria brizantha cv. BRS Ipyporã interspecific hybrid ("Ipyporã grass") were implemented in January 2012 (EUCLIDES et al., 2018). Upon establishment, soil correction and fertilization were carried out according to the result of soil analysis (EUCLIDES et al., 2018). The pastures were used under grazing activity until October 2015 (ECHEVERRIA et al., 2016; TAIRA, 2017; EUCLIDES et al., 2018), when maintenance fertilization was performed using $60 \mathrm{~kg}$ $\mathrm{ha}^{-1} \mathrm{P}_{2} \mathrm{O}_{5}$ and $60 \mathrm{~kg} \mathrm{ha}^{-1} \mathrm{~K}_{2} \mathrm{O}$, based on soil analysis of the experimental area. The 0-20 cm layer showed the following properties: $\mathrm{pH} \mathrm{CaCl}_{2}=5.17 ; \mathrm{P}=5.04$ $\mathrm{mg} \mathrm{dm}{ }^{-3}$; organic mater $=30.02 \mathrm{~g} \mathrm{dm}^{-3} ; \mathrm{K}=0.48 \mathrm{cmol}$ $\mathrm{dm}^{-3} ; \mathrm{Ca}=2.96 \mathrm{cmol} \mathrm{dm}^{-3} ; \mathrm{Mg}=1.09 \mathrm{cmol} \mathrm{dm}^{-3} ; \mathrm{Ca}+$ $\mathrm{Mg}=4.05 \mathrm{cmol} \mathrm{dm}^{-3} ; \mathrm{Al}=0.015 \mathrm{cmol} \mathrm{dm}^{-3} ; \mathrm{H}=5.34$ $\mathrm{cmol} \mathrm{dm}{ }^{-3} ; \mathrm{Al}+\mathrm{H}=5.36 \mathrm{cmol} \mathrm{dm}^{-3} ; \mathrm{S}=4.54 \mathrm{cmol}$ $\mathrm{dm}^{-3}$; cation-exchange capacity $=9.91 \mathrm{cmol} \mathrm{dm}^{-3}$; base saturation $=45.97 \%$.

The experimental area was sectioned into three blocks, which were divided into two 0.75-ha modules. Each module was then subdivided into four paddocks (0.19 ha). Accordingly, the experiment was laid out in a randomized-block design with two treatments and three replicates (modules of four paddocks). The treatments consisted of two $\mathrm{N}$ fertilization rates: 100 and $200 \mathrm{~kg} \mathrm{ha}^{-1}$. Urea was used as the $\mathrm{N}$ source, which was split into two applications for the rate of $100 \mathrm{~kg} \mathrm{ha}^{-1}$ and four applications for the rate of $200 \mathrm{~kg} \mathrm{ha}^{-1}$, during the rainy season (November to March).

Intermittent grazing was implemented with a variable stocking rate. The criteria for animal entry and exit into and out of the paddocks were kept fixed for the two $\mathrm{N}$ rates applied, namely, a height of 30 $\mathrm{cm}$ in the pre-grazing condition (corresponding to 90$95 \%$ LI by the forage canopy) and $15 \mathrm{~cm}$ post-grazing (ECHEVERRIA et al., 2016). To reach the postgrazing targets, 90 Brangus calves with an average initial weight of $200 \pm 23 \mathrm{~kg}$ and an average age of 9 \pm 2 months were used. Stocking rate was calculated as the sum of the days the animals remained in each of the five paddocks ( 0.19 ha) divided by the total 


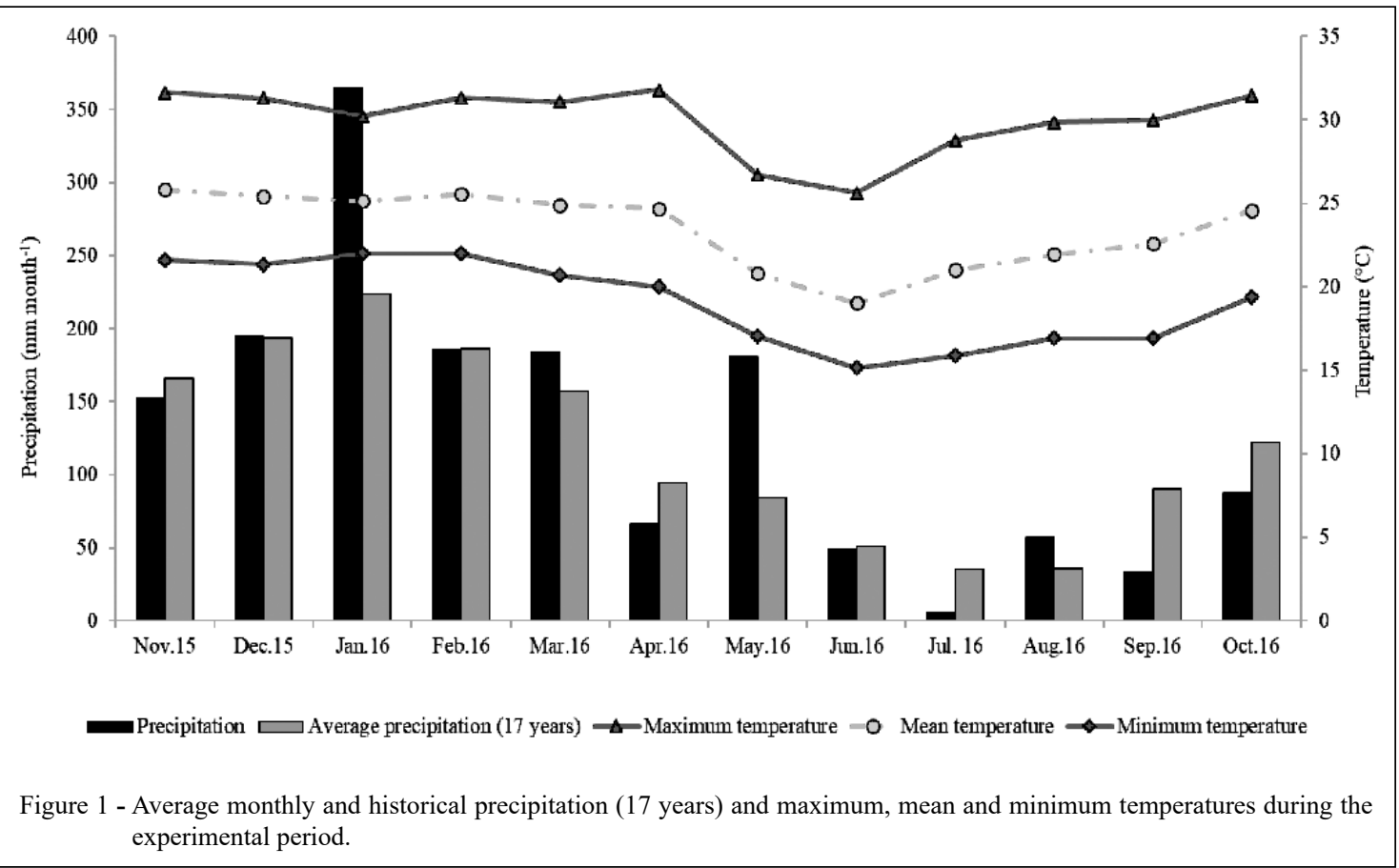

number of grazing days and then by the area of each module (0.94 ha). The average stocking rate for the $\mathrm{N}$ rates of 100 and $200 \mathrm{~kg} \mathrm{ha}^{-1}$ was 3.3 and 3.9 animal units (450 kg live weight) per hectare, respectively (TAIRA, 2017).

The pre- and post-grazing heights were measured at 20 points per paddock using a ruler graduated in centimeters. The light intercepted by the canopy was estimated using a canopy analyzer (PAR - 80 AccuPAR Linear PAR/LAI ceptometer; DECAGON Devices), at 20 random points per paddock. At each point, one reading was taken at the top of the canopy and another one close to the ground.

At the entrance and exit of the animals, nine samples were harvested per paddock, close to ground level, using a $1 \times 1 \mathrm{~m}$ square frame. Samples were packed and processed according to TAIRA (2017). Based on the results, forage accumulation $\left(\mathrm{kg} \mathrm{DM} \mathrm{ha}{ }^{-1}\right.$ day $\left.^{-1}\right)$ was estimated as the difference between the forage mass in the current pre-grazing and the previous post-grazing condition. To estimate the accumulation rate (FAR, $\mathrm{kg} \mathrm{DM} \mathrm{ha}{ }^{-1}$ day $\left.^{-1}\right)$, the total leaf + stem accumulation values were divided by the grazing interval (days) of each cycle. Leaf:stem ratio (LSR) was calculated by dividing the average leaf percentage by the average stem percentage in each paddock and cycle.

After the animals left the paddocks, 10 tillers were marked per paddock to determine their morphogenetic and structural traits. The tillers were identified with colored threads and measured weekly using a ruler graduated in centimeters. The heights of the pseudostem and the extended tiller and the length of each leaf were measured to estimate the following variables: leaf appearance rate (LAR, leaves tiller ${ }^{-1}$ day $^{-1}$ ); phyllochron (days leaf ${ }^{-1}$ tiller $^{-1}$ ); leaf elongation rate (LER, cm tiller-1 day $^{-1}$ ); stem elongation rate (SER, $\mathrm{cm}$ tiller $^{-1}$ day $^{-1}$ ); final leaf length (FLL, cm tiller ${ }^{-1}$ ); leaf senescence rate (LSR, $\mathrm{cm}_{\text {tiller }}^{-1}$ day $^{-1}$ ); number of live leaves (NLL, leaves tiller ${ }^{-1}$ ); and leaf lifespan (LLS, days), which was estimated as proposed by LEMAIRE \& CHAPMAN (1996).

Tiller density (TD) was estimated at three points per paddock. An iron square measuring 1.00 $\times 0.25 \mathrm{~m}\left(0.25 \mathrm{~m}^{2}\right)$ was used as a template within which all tillers were counted and classified as basal, aerial or reproductive. Evaluations were carried out in the pre-grazing condition, in two paddocks per module. The counting points were kept fixed. These were marked with wooden stakes throughout the experimental period and changed only if they did not represent the average condition of the paddocks.

Data were analyzed statistically using a mathematical model that included the random effect of blocks and the fixed effects of treatments, seasons and their interactions. The Mixed procedure available in SAS software (SAS Institute, 1996) was used for 
the analyses. Means were compared by Tukey's test, adopting the $5 \%$ probability level. In the case of significant interactions, the means were compared by difference probability and Tukey's test at the $5 \%$ probability level.

\section{RESULTS AND DISCUSSION}

Light interception averaged $92.25 \pm$ $0.42 \%$, which is within the predefined target of 90 $95 \%$. The average pre-grazing height associated with LI was $26.62 \pm 0.48 \mathrm{~cm}$ and the average postgrazing height was $16.31 \pm 0.56 \mathrm{~cm}$, which can be considered close to the pre-established target of $15 \mathrm{~cm}$. Ipyporã grass pastures managed under intermittent grazing by beef cattle achieve 95\% LI upon reaching an average canopy height of 29.6 cm (ECHEVERRIA et al., 2016), a value similar to those observed in the present experiment.

It is worth noting that, on tropical forage grasses, $95 \%$ LI by the forage canopy is the maximum limit for grazing management. In pastures managed with a pre-grazing condition of over $95 \%$ LI, stem elongation and forage losses are pronounced due to senescence (CARNEVALLI et al., 2006; ECHEVERRIA et al., 2016). Conversely, when grazing is performed more frequently $(90-95 \% \mathrm{LI})$, there are no changes in pasture structure or animal performance. Nonetheless, the produced forage is better utilized (SBRISSIA et al., 2018; ALVARENGA et al., 2020).

There was a significant interaction effect $(\mathrm{P}<0.05)$ between $\mathrm{N}$ rates and seasons for the rest period, phyllochron, LLS, SER and FLL (Table 1). During summer, spring and fall, the $\mathrm{N}$ rates did not influence the rest period. In winter; however, the rest period was shorter in the pastures fertilized with $200 \mathrm{~kg} \mathrm{ha}^{-1} \mathrm{~N}$. Conversely, in this season, the pastures fertilized with $100 \mathrm{~kg} \mathrm{ha}^{-1} \mathrm{~N}$ showed higher phyllochron, LLS and SER values and lower FLL values. In the other seasons of the year, phyllochron, LLS, SER and FLL did not change in response to the $\mathrm{N}$ rates (Table 2). When the pastures were fertilized with $100 \mathrm{~kg} \mathrm{ha}^{-1} \mathrm{~N}$, the rest period was longer in the fall and winter. However, with the use of $200 \mathrm{~kg} \mathrm{ha}^{-1}$ $\mathrm{N}$, the rest period was only longer in the fall. At the $\mathrm{N}$ rate of $200 \mathrm{~kg} \mathrm{ha}^{-1}$, phyllochron, LLS and SER did not change between the seasons of the year. On the other

Table 1 - Probability values (P-value) for the effects of nitrogen rates, seasons of the year and interaction between nitrogen rates $\times$ seasons for variables evaluated in Ipyporã grass pastures fertilized with nitrogen.

\begin{tabular}{|c|c|c|c|}
\hline Variable & $\mathrm{N}$ rate & Season & $\mathrm{N}$ rates $\times$ Seasons \\
\hline Rest period (days) & 0.7328 & 0.0000 & 0.0167 \\
\hline FAR $\left(\mathrm{kg} \mathrm{ha}^{-1}\right.$ day $\left.^{-1}\right)$ & 0.3699 & $<0.0001$ & 0.2297 \\
\hline Leaves $(\%)$ & 0.0100 & 0.0100 & 0.3561 \\
\hline LAR (leaves tiller ${ }^{-1}$ day $^{-1}$ ) & 0.6812 & $<0.0001$ & 0.4431 \\
\hline LER (cm tiller ${ }^{-1}$ day $\left.^{-1}\right)$ & 0.6179 & $<0.0001$ & 0.0754 \\
\hline LLS (days) & 0.5044 & $<0.0001$ & 0.0000 \\
\hline Phyllochron (days) & 0.6086 & $<0.0001$ & 0.0000 \\
\hline LSR (cm tiller ${ }^{-1}$ day $^{-1}$ ) & 0.2049 & 0.0012 & 0.2029 \\
\hline SER (cm tiller ${ }^{-1}$ day $^{-1}$ ) & 0.8405 & 0.4819 & 0.0068 \\
\hline FLL $(\mathrm{cm})$ & 0.2323 & $<0.0001$ & 0.0149 \\
\hline NLL (leaves tiller ${ }^{-1}$ ) & 0.9812 & $<0.0001$ & 0.4524 \\
\hline $\mathrm{L}: \mathrm{S}$ & 0.9042 & 0.0085 & 0.3812 \\
\hline Basal TD (tillers ${ }^{-1} \mathrm{~m}^{2}$ ) & 0.4470 & $<0.0001$ & 0.8853 \\
\hline Aerial TD (tillers $\left.{ }^{-1} \mathrm{~m}^{2}\right)$ & 0.5970 & $<0.0001$ & 0.6394 \\
\hline Reproductive TD (tillers ${ }^{-1} \mathrm{~m}^{2}$ ) & 0.1136 & $<0.0001$ & 0.1779 \\
\hline Total TD (tillers ${ }^{-1} \mathrm{~m}^{2}$ ) & 0.4876 & $<0.0001$ & 0.8615 \\
\hline
\end{tabular}

FAR: forage accumulation rate; LAR: leaf appearance rate; LER: leaf elongation rate; LLS: leaf lifespan; LSR: leaf senescence rate; SER: stem elongation rate; FLL: final leaf length; NLL: number of live leaves per tiller; L:S: leaf:stem ratio; TD: tiller density. 
Table 2 - Interaction effects between nitrogen rates and seasons on rest period, leaf lifespan, phyllochron, stem elongation rate and final leaf length of Ipyporã grass pastures.

\begin{tabular}{|c|c|c|c|}
\hline Season & $100 \mathrm{~kg} \mathrm{ha}^{-1}$ & $200 \mathrm{~kg} \mathrm{ha}^{-1}$ & SEM \\
\hline \multicolumn{4}{|c|}{ 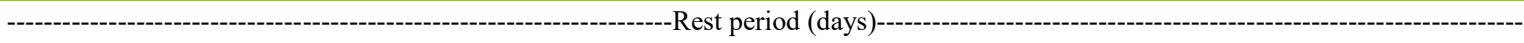 } \\
\hline Spring & $37.40^{\mathrm{aB}}$ & $41.80^{\mathrm{aAB}}$ & 3.94 \\
\hline Summer & $32.33^{\mathrm{aB}}$ & $38.40^{\mathrm{aB}}$ & 3.05 \\
\hline Fall & $61.00^{\mathrm{aA}}$ & $54.12^{\mathrm{aA}}$ & 3.78 \\
\hline Winter & $50.00^{\mathrm{aA}}$ & $40.00^{\mathrm{bB}}$ & 2.98 \\
\hline SEM & 3.19 & 3.30 & \\
\hline \multicolumn{4}{|c|}{ 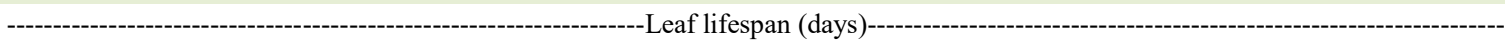 } \\
\hline Spring & $50.96^{\mathrm{aB}}$ & $45.80^{\mathrm{aA}}$ & 14.67 \\
\hline Summer & $49.57^{\mathrm{aB}}$ & $48.50^{\mathrm{aA}}$ & 19.21 \\
\hline Fall & $83.24^{\mathrm{aB}}$ & $81.34^{\mathrm{aA}}$ & 15.29 \\
\hline Winter & $282.50^{\mathrm{aA}}$ & $54.35^{\mathrm{bA}}$ & 28.81 \\
\hline SEM & 13.45 & 11.49 & \\
\hline \multicolumn{4}{|c|}{ - } \\
\hline Spring & $11.00^{\mathrm{aB}}$ & $10.00^{\mathrm{aA}}$ & 6.76 \\
\hline Summer & $10.90^{\mathrm{aB}}$ & $9.98^{\mathrm{aA}}$ & 5.16 \\
\hline Fall & $23.99^{\mathrm{aB}}$ & $23.46^{\mathrm{aA}}$ & 5.38 \\
\hline Winter & $81.00^{\mathrm{aA}}$ & $15.57^{\mathrm{bA}}$ & 10.14 \\
\hline SEM & 5.76 & 4.06 & \\
\hline \multicolumn{4}{|c|}{ 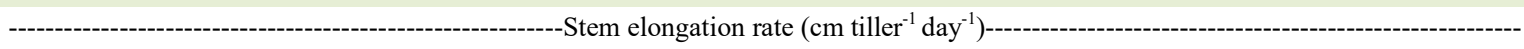 } \\
\hline Spring & $0.010^{\mathrm{aB}}$ & $0.044^{\mathrm{aA}}$ & 0.020 \\
\hline Summer & $0.022^{\mathrm{aB}}$ & $0.008^{\mathrm{aA}}$ & 0.016 \\
\hline Fall & $0.014^{\mathrm{aB}}$ & $0.028^{\mathrm{aA}}$ & 0.016 \\
\hline Winter & $0.139^{\mathrm{aA}}$ & $0.004^{\mathrm{bA}}$ & 0.031 \\
\hline SEM & 0.021 & 0.018 & \\
\hline \multicolumn{4}{|c|}{ - } \\
\hline Spring & $10.96^{\mathrm{aA}}$ & $11.57^{\mathrm{aA}}$ & 0.49 \\
\hline Summer & $8.72^{\mathrm{aB}}$ & $9.52^{\mathrm{aB}}$ & 0.37 \\
\hline Fall & $8.23^{\mathrm{aB}}$ & $8.24^{\mathrm{aB}}$ & 0.39 \\
\hline Winter & $6.20^{\mathrm{bC}}$ & $9.63^{\mathrm{aB}}$ & 0.73 \\
\hline SEM & 0.51 & 0.43 & \\
\hline
\end{tabular}

Means followed by lowercase letters in the same row differ from each other by Tukey's test $(\mathrm{P}<0.05)$; SEM: standard error of the mean.

hand, at the $\mathrm{N}$ rate of $100 \mathrm{~kg} \mathrm{ha}^{-1}$, phyllochron, LLS, and SER were higher during winter.

The observed interactions between $\mathrm{N}$ rates and seasons are a result of morphogenetic and structural responses of plants to abiotic factors that regulate growth (LEMAIRE \& CHAPMAN, 1996). The higher $\mathrm{N}$ rate applied had a noteworthy effect on the rest period, phyllochron, LLS and SER. When fertilized with $200 \mathrm{~kg} \mathrm{ha}^{-1} \mathrm{~N}$, cultivar Ipyporã showed a similar behavior through all seasons of the year. When $\mathrm{N}$ was applied at the rate of $100 \mathrm{~kg} \mathrm{ha}^{-1}$, however, the grass exhibited the typical seasonal behavior of tropical forages during the dry season. Based on the results of morphogenetic traits, fertilization with a higher $\mathrm{N}$ level $\left(200 \mathrm{~kg} \mathrm{ha}^{-1}\right)$ can be used as a tool to reduce production seasonality in Ipyporã grass, as it ensures the maintenance of tissue turnover rate, which may translate into higher quantity and quality of forage for the system throughout the year.

Final leaf length, a genetically determined structural trait of the forage canopy, decreased less over the seasons when Ipyporã grass was fertilized 
with $200 \mathrm{~kg} \mathrm{ha}^{-1} \mathrm{~N}$. This variable is important, as it can change the leaf area index (FERNANDES et al., 2020) and; consequently, the amount of light intercepted by the forage canopy (MARTINS et al., 2021). Thus, the higher FLL observed in the pastures fertilized with $200 \mathrm{~kg} \mathrm{ha}^{-1} \mathrm{~N}$ during winter may be one of the causes of the shorter rest period seen in these pastures. Final leaf length also influences the ease of forage prehension by grazing animals, since cattle remove $50 \%$ of the leaf blade with each bite (LACA et al., 1992; PAULA et al., 2012). Therefore, smaller leaves can hinder the daily forage intake capacity due to the reduced bite volume. This phenomenon was more marked in winter when the pastures were fertilized with $100 \mathrm{~kg} \mathrm{ha}^{-1} \mathrm{~N}$.

There was no interaction effect between $\mathrm{N}$ fertilization and seasons on FAR, LAR, LER, LSR, NLL, LSR or TD (basal, aerial, reproductive or total) (Table 1). Likewise, the $\mathrm{N}$ rates in isolation did not affect these variables, whose respective means and standard errors were $28.21 \pm 1.64 \mathrm{~kg} \mathrm{ha}^{-1}$ day $^{-1}, 0.08 \pm$ 0.01 leaves tiller ${ }^{-1}$ day $^{-1}, 1.02 \pm 0.10 \mathrm{~cm}_{\text {tiller }}{ }^{-1}$ day $^{-1}$, $0.58 \pm 0.03 \mathrm{~cm}^{-1}$ tiler $^{-1}$ day $^{-1}, 4.27 \pm 0.18$ leaves tiller ${ }^{-1}$, $3.93 \pm 0.88,903.94 \pm 27.58$ tillers $\mathrm{m}^{-2}, 63.62 \pm 14.06$ tillers $\mathrm{m}^{-2}, 27.78 \pm 5.22$ tillers $\mathrm{m}^{-2}$ and $967.57 \pm 41.05$ tillers $\mathrm{m}^{-2}$, respectively. There was also no interaction effect between $\mathrm{N}$ rates and seasons on the percentage of leaves. However, this variable was affected by the $\mathrm{N}$ rates in isolation, with the level of $200 \mathrm{~kg} \mathrm{ha}^{-1}$ providing higher percentages $(63.5 \%$ vs $56.7 \%)$.

Information about the behavior of morphogenetic variables in BRS Ipyporã is still scarce, as it is a new interspecific hybrid in the production system. Although, these variables were expected to respond to the tested $\mathrm{N}$ rates, it is possible that their maximum genetic expression was achieved at the lower rate $\left(100 \mathrm{~kg} \mathrm{ha}^{-1} \mathrm{~N}\right)$, as this level represents the minimum recommended for Brachiaria cultivars under grazing activity (MARTHA JÚNIOR et al., 2007).

Grazing control, which was based on LI and the canopy height and identical for both $\mathrm{N}$ rates applied, may have been decisive for the lack of variations between treatments. Ipyporã grass shows a plastic behavior of escape to grazing, whereby it displays very characteristic changes in its growth habit, leaf size and stem length when compared with its free growth as described by VALLE et al. (2017). This behavior, coupled with its lower forage accumulation in comparison to $B$. brizantha cultivars (EUCLIDES et al., 2018) or Brachiaria hybrids (PARAISO et al., 2019), may explain the greater stability of morphogenetic and structural traits of the grass in response to the $\mathrm{N}$ fertilization levels.

Forage accumulation rate was higher in spring and summer; intermediate in the fall; and lower in winter (Table 3). This is a typical seasonal behavior of tropical forage cultivars (SBRISSIA et al., 2020), which reduce their net forage accumulation in the absence of abiotic factors such as light, temperature and water (Figure 1). ECHEVERRIA et al. (2016) and EUCLIDES et al. (2018) reported higher FAR (43 kg/ha DM) in Ipyporã grass pastures in the first year of use. The lower FAR found in the

Table 3 - Effect of seasons of the year on variables evaluated in Ipyporã grass pastures fertilized with nitrogen rates.

\begin{tabular}{|c|c|c|c|c|c|}
\hline \multirow[t]{2}{*}{ Variable } & \multicolumn{4}{|c|}{ 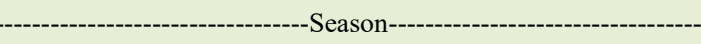 } & \multirow[t]{2}{*}{ SEM } \\
\hline & Spring & Summer & Fall & Winter & \\
\hline FAR $\left(\mathrm{kg} \mathrm{ha}^{-1}\right.$ day $\left.^{-1}\right)$ & $38.22^{\mathrm{a}}$ & $39.66^{\mathrm{a}}$ & $29.07^{\mathrm{a}}$ & $10.87^{\mathrm{b}}$ & 2.998 \\
\hline Leaves $(\%)$ & $69.8^{\mathrm{a}}$ & $69.0^{\mathrm{a}}$ & $51.9^{\mathrm{b}}$ & $42.6^{\mathrm{c}}$ & 2.550 \\
\hline LAR (leaves tiller ${ }^{-1}$ day $^{-1}$ ) & $0.096^{\mathrm{a}}$ & $0.098^{\mathrm{a}}$ & $0.056^{\mathrm{b}}$ & $0.034^{\mathrm{b}}$ & 0.007 \\
\hline LER (cm tiller ${ }^{-1}$ day $^{-1}$ ) & $1.460^{\mathrm{a}}$ & $1.254^{\mathrm{a}}$ & $0.629^{\mathrm{b}}$ & $0.546^{\mathrm{b}}$ & 0.085 \\
\hline LSR (cm tiller ${ }^{-1}$ day $^{-1}$ ) & $0.774^{\mathrm{a}}$ & $0.595^{\mathrm{a}}$ & $0.531^{\mathrm{b}}$ & $0.305^{\mathrm{b}}$ & 0.067 \\
\hline NLL (leaves tiller ${ }^{-1}$ ) & $4.73^{\mathrm{a}}$ & $4.67^{\mathrm{a}}$ & $3.71^{\mathrm{b}}$ & $3.73^{\mathrm{b}}$ & 0.150 \\
\hline $\mathrm{L}: \mathrm{S}$ & $7.73^{\mathrm{a}}$ & $3.40^{\mathrm{b}}$ & $3.00^{\mathrm{b}}$ & $3.12^{\mathrm{b}}$ & 0.910 \\
\hline
\end{tabular}

Means followed by lowercase letters in the same row differ from each other by Tukey's test $(\mathrm{P}<0.05)$; FAR: forage accumulation rate; LAR: leaf appearance rate; LER: leaf elongation rate; LSR: leaf senescence rate; NLL: number of live leaves per tiller; L:S: leaf:stem ratio; SEM: standard error of the mean. 
present study may be explained by the fact that this is the fourth year of use of the pastures. According to MACEDO (2006), pastures evaluated in their first year after establishment can have an up to $40 \%$ higher productive capacity than older pastures. Despite being a trait associated with plant vigor and adequate formation, the application of recommended maintenance fertilization and grazing management practices is a tool capable of reducing this production decline in pastures.

Leaf appearance rate, LER, NLL and leaf percentage were higher in spring and summer, whose results differed from those observed in the fall and winter, which were similar (Table 3). Spring and summer are the seasons with the highest accumulated rainfall and mean temperatures (Figure 1) and also the period when maintenance fertilization and $\mathrm{N}$ fertilization are carried out. These abiotic factors, which may or may not be manipulated by human action, are responsible for the greater accumulation of forage in tropical grasses (FARIAS et al., 2019; SBRISSIA et al., 2020). Therefore, the appearance and elongation rates tend to be high. Agreeing with this, plants are able to fully express their genetic potential (NLL), as they find an abundance of nutrients and adequate climatic conditions.

Leaf senescence rate was also higher in spring and summer. Results for these seasons differed from those observed in winter, when the lowest values were recorded. In the fall, LSR values were similar to those found in all other seasons. Besides the fact that the growth of new tissues was favored during the rainy season, increases in tissue senescence and death rates are expected due to the plant turnover process. Nitrogen, which is applied in the rainy season, is responsible for accelerating organic matter decomposition (MARTHA JÚNIOR et al., 2007), increasing tissue appearance, elongation and senescence rates (LEMAIRE \& CHAPMAN, 1996). Leaf:stem ratio was highest in spring and similar between the other three seasons (Table 3). These responses reflect the seasonal behavior of LAR and LER, which are responsible for the increased amount of leaves in the canopy in these seasons.

The Ipyporã grass pastures showed a higher basal TD during spring, summer and fall. Total TD also differed between the seasons of the year, with the highest values occurring in summer. Total TD in spring and fall were similar to the values recorded in the other two seasons (Table 4). These differences can be explained by the higher rainfall accumulation and temperatures in spring, summer and fall (Figure 1). In addition, maintenance fertilization and $\mathrm{N}$ fertilization were applied during that period. The association of these factors increased LAR (Table 3), which is considered a key characteristic of morphogenesis (LEMAIRE \& CHAPMAN, 1996) and is responsible for the appearance of new phytomers (leaf blade, sheath, ligula, node, internode, axillary bud and roots) that will potentially give rise to new tillers (VALENTINE \& MATTHEW, 1999).

Aerial TD was highest in the fall and lowest in spring. During winter and summer, the pastures showed an aerial TD value similar to those recorded in other two seasons. Reproductive tillers were observed only in the fall and winter (Table 4). These fluctuations in the number of aerial and reproductive tillers could be partially explained by the flowering time of the cultivar used. In the municipality of Campo Grande ( $20^{\circ} 27^{\prime}$ S latitude), cultivar Ipyporã starts flowering in March and is in full bloom in the first half of April (VALLE et al., 2017), which are months that coincide with fall and winter.

Table 4 - Effect of seasons on basal, aerial, reproductive and total tiller density in Ipyporã grass pastures fertilized with nitrogen rates.

\begin{tabular}{|c|c|c|c|c|c|}
\hline \multirow[t]{2}{*}{ Tiller density (tillers $\mathrm{m}^{-2}$ ) } & \multicolumn{4}{|c|}{--------------------------------------S Season-----------------------------------. } & \multirow[t]{2}{*}{ SEM } \\
\hline & Spring & Summer & Fall & Winter & \\
\hline Basal & $896.00^{\mathrm{a}}$ & $1018.81^{\mathrm{a}}$ & $914.40^{\mathrm{a}}$ & $710.67^{\mathrm{b}}$ & 40.56 \\
\hline Aerial & $15.03^{\mathrm{b}}$ & $69.09^{\mathrm{ab}}$ & $108.00^{\mathrm{a}}$ & $46.90^{\mathrm{ab}}$ & 10.48 \\
\hline Reproductive & $0.00^{\mathrm{b}}$ & $0.00^{\mathrm{b}}$ & $78.76^{\mathrm{a}}$ & $46.27^{\mathrm{a}}$ & 12.13 \\
\hline Total & $911.03^{\mathrm{ab}}$ & $1087.91^{\mathrm{a}}$ & $1022.40^{\mathrm{ab}}$ & $757.58^{\mathrm{b}}$ & 45.22 \\
\hline
\end{tabular}

Means followed by lowercase letters in the same row differ from each other by Tukey's test $(\mathrm{P}<0.05)$; SEM: standard error of the mean. 


\section{CONCLUSION}

The use of $200 \mathrm{~kg} \mathrm{ha-1}$ nitrogen in Ipyporã grass pastures reduces its forage production seasonality and can be used as a pasture management practice to ensure greater utilization of the cultivar during the dry season and transition periods.

\section{ACKNOWLEDGMENTS}

The authors thank Coordination for the Coordenação de Aperfeiçoamento de Pessoal de Nível Superior - Brazil (CAPES) - Finance Code 001. Thanks are also due to the Empresa Brasileira de Pesquisa Agropecuária (EMBRAPA Beef Cattle), the Conselho Nacional de Desenvolvimento Científico e Tecnológico (CNPq), the Fundação de Apoio ao Desenvolvimento do Ensino, Ciência e Tecnologia do Estado de Mato Grosso do Sul (FUNDECT) and the Federal University of Mato Grosso do Sul for their support.

\section{DECLARATION OF CONFLICT OF} INTEREST

The authors declare that they have no conflict of interest.

\section{AUTHORS' CONTRIBUTIONS}

All authors contributed equally to the conception and writing of the manuscript. All authors reviewed the manuscript critically and approved the final version.

\section{REFERENCES}

ALVARENGA, C. A. F. et al. Animal performance and sward characteristics of Mombaça guineagrass pastures subjected to two grazing frequencies. Tropical Grasslands-Forrajes Tropicales, v.8, n.1, p.1-10, 2020. Available from: <http://dx.doi.org/10.17138/ TGFT(8)1-10>. Accessed: Dec. 12, 2020. doi: 10.17138/TGFT(8)1-10.

CARNEVALLI, R. A. et al. Herbage production and grazing losses in Panicum maximum cv. Mombaça under four grazing managements. Tropical Grasslands, v.40, n.1, p.165-176, 2006. Available from: $\quad<$ https://tropicalgrasslands.info/public/journals/4/Historic/ Tropical\%20Grasslands\%20Journal\%20archive/PDFs/Vol 40 2006/ Vol_40_03_2006_pp165_176.pdf>.Accessed: Dec. 12, 2020.

CASTAGNARA, D. D. et al. Nutritional value and structural characteristics of tropical grasses under nitrogen fertilization. Archivos de Zootecnia, v.60, n.232, p.931-942, 2011. Available from: $\quad<$ http://dx.doi.org/10.4321/S0004-05922011000400010>. Accessed: Accessed: Dec. 12, 2020. doi: 10.4321/S000405922011000400010

ECHEVERRIA, J. R. et al. Forage accumulation and nutritive value of the Urochloa interspecific hybrid 'BRS RB331 Ipyporã' under intermittent grazing. Pesquisa Agropecuária Brasileira, v.51, n.7, p.880-889, 2016. Available from: <http://dx.doi. org/10.1590/S0100-204X2016000700011>. Accessed: Dec. 12, 2020. doi: 10.1590/S0100-204X2016000700011.

EMBRAPA - Centro Nacional de Pesquisa de Solos. Sistema Brasileiro de Classifcação de Solos (3nd ed.). Rio de Janeiro,
2013. Available from: <https://www.embrapa.br/buscadepublicacoes/-/publicacao/1094003/sistema-brasileirodeclassifcacao-de-solos>. Accessed: Dec. 12, 2020.

EUCLIDES, V. P. B. et al. Beef cattle performance in response to Ipyporã and Marandu brachiariagrass cultivars under rotational stocking management. Revista Brasileira de Zootecnia, v.47, e20180018, 2018. Available from: <http://dx.doi.org/10.1590/ rbz4720180018>. Accessed: Dec. 12, 2020. doi: 10.1590/ rbz4720180018.

FARIAS, L. N. et al. Effects of nitrogen fertilization and seasons on the morphogenetic and structural characteristics of Piatã (Brachiaria brizantha) grass. Revista de la Facultad de Ciencias Agrarias, v.51, n.2, p.42-54, 2019. Available from: $<$ http://revistas. uncu.edu.ar/ojs/index.php/RFCA/article/view/2592/1934>. Accessed: Dec. 12, 2020.

FERNANDES, P. B. et al. Evaluation and reparametrization of mathematical models for prediction of the leaf area of Megathyrsus maximus cv. BRS Zuri. Tropical Grasslands-Forrajes Tropicales, v.8, n.3, p.214-219, 2020. Available from: <http:// dx.doi.org/10.17138/TGFT(8)214-219>. Accessed: Dec. 12, 2020. doi: 10.17138/TGFT(8)214-219.

GIMENES, F. M. A. et al. Weight gain and animal productivity on Marandu palisade grass under rotational stocking and nitrogen fertilization. Pesquisa Agropecuária Brasileira, v.46, n.7, p.751759, 2011. Available from: <http://dx.doi.org/10.1590/S0100204X2011000700011>. Accessed: Dec. 12, 2020. doi: 10.1590/ S0100-204X2011000700011.

GURGEL, A. L. C. et al. Principal component analysis of steers performance and structural and nutritional characteristics of Mombasa grass. Ciência Rural, v.51, n.1, e20200306, 2021. Available from: <http://dx.doi.org/10.1590/01038478cr20200306>. Accessed: Dec. 12, 2020. doi: 10.1590/0103$8478 \mathrm{cr} 20200306$.

LACA, E. A. et al. Effects of sward height and bulk density on bite dimensions of cattle grazing homogeneous swards. Grass and Forage Science, v.47, n.1, p.91-103, 1992. Available from: <http:// dx.doi.org/10.1111/j.1365-2494.1992.tb02251.x>. Accessed: Dec. 12, 2020. doi: 10.1111/j.1365-2494.1992.tb02251.x.

LEMAIRE, G.; CHAPMAN, D. Tissue flows in grazed plant communities. In: HODGSON, J. and ILliUS, A.W., The ecology and management of grazing systems, New York: CAB International, 1996. Cap.1, p.3-36.

MACEDO, M. C. M.; VALÉRIO, J. R. Considerações sobre a mortalidade de plantas forrageiras em pastagens nas regiões Centro-oeste e Norte do Brasil. In: BARBOSA, R. A., morte de pastos de braquiárias, Campo Grande, EMBRAPA-CNPGC, 2006. Cap.11, p.199-206.

MARTHA JÚNIOR, G. B. et al. Adubação Nitrogenada. In: MARTHA JÚNIOR, G. B., VILELA, L. and SOUSA, D. M. G., Cerrado: uso eficiente de corretivos e fertilizantes em pastagens, Planaltina, Embrapa Cerrados, 2007. Cap.6, p. 117-144.

MARTINS, C. D. M. et al. Defoliation intensity and leaf area index recovery in defoliated swards: implications for forage accumulation. Scientia Agricola, v.78, n.2, e20190095, 2021. Available from: $<$ http://dx.doi.org/10.1590/1678-992X-2019-0095>. Accessed: Dec. 12, 2020. doi: 10.1590/1678-992X-2019-0095. 
MONTAGNER, D. B. et al. Morphogenesis in guinea grass pastures under rotational grazing strategies. Revista Brasileira de Zootecnia, v.41, n.4, p.883-888, 2012. Available from: <http:// dx.doi.org/10.1590/S1516-35982012000400008>. Accessed: Dec. 12, 2020. doi: 10.1590/S1516-35982012000400008.

PARAISO, I. G. N. et al. Herbage accumulation, nutritive value, and organic reserves of continuously stocked 'Ipyporã' and 'Mulato II' Brachiariagrasses. Crop Science, v.59, n.1, 1-12, 2019. Available from: <http://dx.doi.org/10.2135/cropsci2019.06.0399>. Accessed: Dec. 12, 2020. doi: 10.2135/cropsci2019.06.0399.

PAULA, C. C. L. et al. Herbage accumulation, morphogenetic and structural characteristics in marandu palisadegrass under grazing heights. Ciência Rural, v.42, n.11, p.2059-2065, 2012. Available from: <http://dx.doi.org/10.1590/S010384782012005000084>. Accessed: Dec. 12, 2020. doi: 10.1590/ S0103-84782012005000084.

SBRISSIA, A. F. et al. Defoliation strategies in pastures submitted to intermittent stocking method: underlying mechanisms buffering forage accumulation over a range of grazing heights. Crop Science, v.58, n.1, p.945-954, 2018. Available from: <http://dx.doi. org/10.2135/cropsci2017.07.0447>. Accessed: Dec. 12, 2020. doi: 10.2135/cropsci2017.07.0447.

SBRISSIA, A. F. et al. Unravelling the relationship between a seasonal environment and the dynamics of forage growth in grazed swards. Jounal of Agronomy and Crop Science, v.206, n.5, p.630-639, 2020. Available from: <http://dx.doi.org/10.1111/ jac.12402>. Accessed: Dec. 12, 2020. doi: 10.1111/jac.12402.

TAIRA, C. A. Q. Produção animal em pastos de capim-ipyporã sob doses de nitrogênio em lotação intermitente. 2017. $57 \mathrm{f}$ Tese (Doutorado em Ciência Animal) - Curso de Pós-graduação em Ciência Animal, Universidade Federal de Mato Grosso do Sul.

VALENTINE, I. and MATTHEW, C. Plant growth, development and yield. In: New Zealand - Pasture and Crop Science, Oxford, 1999. p. 11-27.

VALLE, C. B. et al. BRS Ipyporã ("belocomeço” em guarani): híbrido de Brachiaria da Embrapa. Comunicado Técnico, v.137, p.1-18, 2017. Available from: <https://ainfo.cnptia.embrapa.br/ digital/bitstream/item/159958/1/BRS-Ipypora-belo-comeco-emguarani.pdf $>$. Accessed: Dec. 12, 2020.

VASCONCELOS, E. C. G. et al. Morphogenesis and biomass production of 'BRS Tamani' guinea grass under increasing nitrogen doses. Pesquisa Agropecuária Brasileira, v.55, e01235, 2020. Available from: $<\mathrm{http}: / /$ dx.doi.org/10.1590/s1678-3921.pab2020.v55.01235>. Accessed: Dec. 12, 2020. doi: 10.1590/s1678-3921.pab2020.v55.01235.

YASUOKA, J. I. et al. Canopy Canopy height and $\mathrm{N}$ affect herbage accumulation and the relative contribution of leaf categories to photosynthesis of grazed brachiariagrass pastures. Grass and Forage Science, v.73, n.1, p.183-192, 2018. Available from: $<$ http://dx.doi.org/ 10.1111/gfs.12302>. Accessed: Dec. 12, 2020. doi: $10.1111 / \mathrm{gfs} .12302$. 